\title{
How I Learned to Read a Film
}

TRANSLATED BY JOEL DAVID

\section{Paull Alcoseba Castillo \\ University of Santo Tomas}

My appreciation for film started when Professor Michael M. Coroza at the graduate program of the University of Santo Tomas used James Cameron's Titanic (1997) as a sample for textual reading. He directed our attention to the final scene where Rose casts her necklace into the ocean while uttering the line "A woman's heart is a deep ocean of secrets," which (per Professor Cordoza's lecture) may be the key to understanding the entire film. In a sense, a lover is submerged by his passion despite his apparent dominant role, and this is symbolized by the ship's representation of masculine pride via the Heart of the Ocean diamond, that was swallowed up in the end by the Atlantic Ocean.

This is the reason I started my Kung Sine Sine Lang blog in 2014, intending it as an exercise in closed reading literary texts via New Criticism, because creative writing was my discipline. As a university instructor, the short Titanic anecdote was my means of introduction to film art and enabled me to teach Art Appreciation, a course under the college's General Education program. But I always add that film reviewing does not end with closed reading, that this activity opens various philosophical and cultural or literary theories. And just like in the example of the Titanic, we find conflicts of gender, politics, and economic situations that surround the characters as well as the text. 
Although I was already taking my master's when the idea of writing on film occurred to me, I'd been a film viewer for a long time. I may have grown up on Hollywood films, but my preference is for independent Filipino releases. I was already in college when I discovered that two of my assignments happened to be "indie" films: Mes de Guzman's Ang Daan Patungong Kalimugtong (2005) and Raya Martin's Maicling Pelicula nañg Ysang Indio Nacional (2005). I also became aware of the then-emerging Cinemalaya Philippine Independent Film Festival, which is the reason I continue to patronize these types of film festivals. I watch out for films that generate buzz or that win in prestigious foreign competitions. I attend all these at venues like the Cultural Center of the Philippines, micro-cinemas, and some theaters allotted by shopping malls.

This bias against mainstream-film products is important because one can find in indie films those products outside the formulas of big studios. Hence since 2014, I devoted my writing to indie films available at film festivals since here, for me, can be found the best of the best of our films. Nevertheless, I still select what films I would criticize or read. If there are six to eight titles in competition, I would not write about two or three of these even if I had seen them. Because aside from providing a favorable or unfavorable review, I also look at each element that the filmmaker utilized for her film and how this revealed a new idea to the audience.

In this perspective, a movie has to transcend the minimum requirement of organic unity, with no wasted scene and element in the vision being conveyed by the director. If the film is unable to meet this requirement, I cannot expect it to provide a fuller meaning for me, and most of all, for the average movie-goer. If I were to compare this to the study and reading of literature, what should follow after a closed reading is the placement of the work within the context of the historical period of the content as well as of the filmmaker.

I wish to clarify that I devote my critical writing to indie movies, which for me is defined not by its budget. A movie becomes indie because of the commercial distributors' failure in providing support to allow audiences to access the work of the filmmaker despite the competition of Western 
releases, especially those that emanate from Hollywood. Because of this, my blog aims to reveal to Filipino viewers what they should expect from the work of "unfamiliar" actors or directors. If they're able to watch but not understand what they see, my reading will enable some of the most significant points of the film.

I believe that what I provide is important in providing the meaning and impact of a work, film or literature, because this is what will enable the audience and the work to come together. For at this time, those who read film evaluations, especially in the form of reviews, may believe that these only serve to declare whether or not a film release should be patronized. We should allow for whatever happens to be screening and avoid dictating the preference of the viewer according to the opinion of the critic. By these means the viewer could learn how to properly patronize films and other art forms in the Philippines. 